\title{
Expression of glutamine metabolism-related proteins in thyroid cancer
}

\author{
Hye Min Kim¹, Yu Kyung Lee ${ }^{1}$, Ja Seung Koo ${ }^{1}$ \\ ${ }^{1}$ Department of Pathology, Yonsei University College of Medicine, Seoul, South Korea \\ Correspondence to: Ja Seung Koo, email: kjs1976@yuhs.ac \\ Keywords: thyroid cancer, glutamine, metabolism, stroma, pathology \\ Received: February 01, $2016 \quad$ Accepted: July 09, $2016 \quad$ Published: July 18, 2016
}

\section{ABSTRACT}

Purpose: This study aimed to investigate the expression of glutamine metabolismrelated protein in tumor and stromal compartments among the histologic subtypes of thyroid cancer.

Results: GLS1 and GDH expression in tumor and stromal compartments were the highest in AC than in other subtypes. Tumoral ASCT2 expression was higher in MC but lower in FC $(p<0.001)$. In PTC, tumoral GLS1 and tumoral GDH expression was higher in the conventional type than in the follicular variant $(p=0.043$ and 0.001 , respectively), and in PTC with BRAF V600E mutation than in PTC without BRAF V600E mutation $(p<0.001)$. Stromal GDH positivity was the independent factor associated with short overall survival (hazard ratio: $21.48,95 \%$ confidence interval: $2.178-211.8$, $p=0.009$ ).

Methods: We performed tissue microarrays with 557 thyroid cancer cases (papillary thyroid carcinoma [PTC]: 344, follicular carcinoma [FC]: 112, medullary carcinoma [MC]: 70, poorly differentiated carcinoma [PDC]: 23, and anaplastic carcinoma [AC]: 8) and 152 follicular adenoma (FA) cases. We performed immunohistochemical staining of glutaminolysis-related proteins (glutaminase 1 [GLS1], glutamate dehydrogenase [GDH], and amino acid transporter-2 [ASCT-2]).

Conclusion: Glutamine metabolism-related protein expression differed among the histologic subtypes of thyroid cancer.

\section{INTRODUCTION}

We aimed to investigate the metabolism in thyroid cancer, especially glutamine metabolism in this study. The typical metabolism of malignant tumors can be explained with the Warburg effect. Most cancer cells produce energy not via a low rate of glycolysis based on oxidation of pyruvate in mitochondria but via a high rate of glycolysis based on lactic acid fermentation in cytosol [1]. Although aerobic glycolysis is one of the most important metabolic pathways, the flexibility of the metabolic system is a major obstacle in cancer treatment. Glutamine metabolism is a critical pathway in cancer cell metabolism [2]. In previous studies, cancer cells have been shown to metabolize glutamine more than other amino acids [3, 4]. Therefore, glutamine metabolism is an important metabolic phenotype of proliferating cancer cells, because it satisfies two important elements of the proliferating cancer cells, i.e., ATP production and supply of intermediates for macromolecular synthesis [2]. Furthermore, in glutamine metabolic pathway, the interaction between cancer cells and stromal cells is present. It was reported that ammonia, which is produced by tumor cell glutaminolysis migrates into the stroma, leading to increased autophagy of stromal cells. Consequently, glutamine was reported to be produced as the product of autophagy activity, travel back to tumor cells and utilized in glutamine metabolism [5-9].

The three proteins that play an important role in glutamine metabolic pathway are the amino acid transporter-2 (ASCT2), the transporter involved in the movement of glutamine into the cell that would be consumed by cancer cells [10]; glutaminase 1 (GLS1), the enzyme that converts glutamine to glutamate [11]; and glutamate dehydrogenase (GDH), the enzyme that converts glutamate to $\alpha$-ketoglutarate to be used in the tricarboxylic acid cycle [12]. 
Thyroid cancer is common, accounting for approximately $1.5 \%$ of the population [13]. The representative subtypes are papillary thyroid carcinoma (PTC), follicular carcinoma (FC), medullary carcinoma (MC), poorly differentiated carcinoma (PDC), and anaplastic carcinoma (AC). The cell origin, clinical manifestation, metastatic pattern, and clinical prognosis are different depending on the histologic subtype [14]. In previous studies of various tumors, differences in the expression of metabolism-related proteins were reported among the histological subtypes [15-18]. Thus, such differences can be expected in thyroid cancer as well; however, much research on this topic is required. Therefore, the purpose of this study was to investigate the expression of glutamine metabolism-related protein in tumor and stromal compartments depending on the subtype of thyroid cancer and its implications on patient prognosis.

\section{RESULTS}

\section{Basal characteristics of patients with thyroid cancer}

This study included 557 cases of thyroid cancer, as follows: 344 cases of PTC, 112 cases of FC, 70 cases of MC, 23 cases of PDC, and 8 cases of AC. The basal characteristics of the patients with PTC are shown in Supplementary Table 2. According to the histologic subtype of PTC, the samples were classified as the conventional type PTC (304 cases) and the follicular variant PTC (40 cases). A higher proportion of follicular variant PTC had expanding tumor margin $(\mathrm{p}=0.002)$. Among the PTC cases, 238 cases (69.18\%) had BRAF V600E mutation. A higher proportion of these cases had infiltrative tumor margin $(\mathrm{p}=0.004)$ but the follicular variant occupied a lower proportion $(\mathrm{p}<0.001)$ (Supplementary Table 2). FC included 99 cases of the minimally invasive type and 13 cases of the widely invasive type. The widely invasive type had a higher proportion of large tumor size $(p=0.040)$, vascular invasion $(\mathrm{p}=0.028)$, extrathyroidal involvement $(\mathrm{p}<$ $0.001)$, and distant metastasis $(\mathrm{p}=0.003)$ (Supplementary Table 3). The basal characteristics of patients with $\mathrm{MC}$, PDC, and AC are shown in Supplementary Table 4.

\section{Expression of glutamine metabolism-related proteins in thyroid cancer}

We investigated the expression of glutamine metabolism-related proteins in thyroid cancer. GLS1 and GDH were expressed in both tumor cells and stroma, but ASCT2 was expressed only in the tumor cells. The expression of glutamine metabolism-related proteins was different according to the histologic subtype of thyroid cancer (Figure 1 and Table 1), where the expression of tumoral GLS1 and tumoral GDH was higher in AC but lower in FC. Stromal GLS1 expression was observed only in $\mathrm{AC}$, and stromal GDH expression was higher in AC.

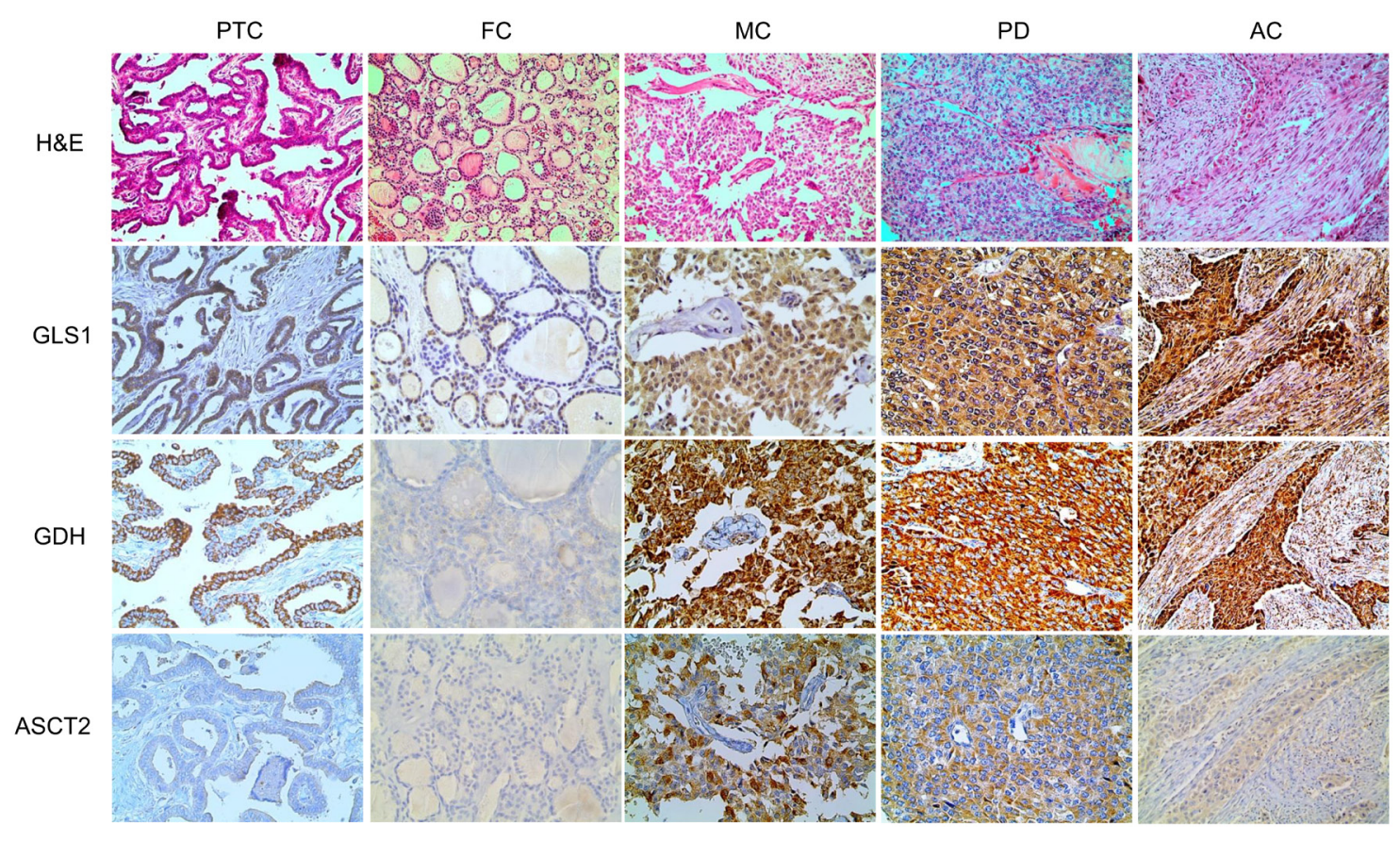

Figure 1: Expression of glutamine metabolism-related proteins according to the histologic subtype of thyroid cancer. The expression of tumoral GLS1 and tumoral GDH is higher in anaplastic carcinoma, but absent in follicular carcinoma; stromal GLS1 and stromal GDH expression are higher in anaplastic carcinoma. Tumoral ASCT2 expression is higher in medullary carcinoma, but absent in follicular carcinoma. The photos of GLS1, GDH, and ASCT2 expression are obtained from the same case of each subtype of thyroid cancer. GLS1; glutaminase 1, GDH; glutamate dehydrogenase, ASCT2; amino acid transporter-2. 
Table 1: Expression of glutamine metabolism-related proteins according to the histologic subtype of thyroid cancer

\begin{tabular}{|c|c|c|c|c|c|c|c|}
\hline Parameters & $\begin{array}{c}\text { Total } \\
\mathrm{N}=\mathbf{5 5 7 ( \% )}\end{array}$ & $\begin{array}{c}\text { PTC } \\
\mathrm{n}=\mathbf{3 4 4}(\%)\end{array}$ & $\begin{array}{c}\text { FC } \\
n=112(\%)\end{array}$ & $\begin{array}{c}\text { MC } \\
n=70(\%)\end{array}$ & $\begin{array}{c}\text { PDC } \\
n=23(\%)\end{array}$ & $\begin{array}{c}\mathrm{AC} \\
n=8(\%)\end{array}$ & p-value \\
\hline GLS1 (T) & & & & & & & $<0.001$ \\
\hline Negative & $247(44.3)$ & $141(41.0)$ & $70(62.5)$ & $27(38.6)$ & $9(39.1)$ & $0(0.0)$ & \\
\hline Positive & $310(55.7)$ & $203(59.0)$ & $42(37.5)$ & $43(61.4)$ & $14(60.9)$ & $8(100.0)$ & \\
\hline GLS1 (S) & & & & & & & $<0.001$ \\
\hline Negative & $554(99.5)$ & $344(100.0)$ & $112(100.0)$ & $70(100.0)$ & $23(100.0)$ & $5(62.5)$ & \\
\hline Positive & $3(0.5)$ & $0(0.0)$ & $0(0.0)$ & $0(0.0)$ & $0(0.0)$ & $3(37.5)$ & \\
\hline GDH (T) & & & & & & & $<0.001$ \\
\hline Negative & 105 (18.9) & $43(12.5)$ & 48 (42.9) & $11(15.7)$ & $3(13.0)$ & $0(0.0)$ & \\
\hline Positive & $452(81.1)$ & $301(87.5)$ & $64(57.1)$ & $59(84.3)$ & $20(87.0)$ & $8(100.0)$ & \\
\hline GDH (S) & & & & & & & $<0.001$ \\
\hline Negative & 549 (98.6) & $341(99.1)$ & $112(100.0)$ & $70(100.0)$ & $22(95.7)$ & $4(50.0)$ & \\
\hline Positive & $8(1.4)$ & $3(0.9)$ & $0(0.0)$ & $0(0.0)$ & $1(4.3)$ & $4(50.0)$ & \\
\hline $\operatorname{ASCT} 2(\mathrm{~T})$ & & & & & & & $<0.001$ \\
\hline Negative & $459(82.4)$ & $289(84.0)$ & $103(92.0)$ & $43(61.4)$ & $17(73.9)$ & $7(87.5)$ & \\
\hline Positive & $98(17.6)$ & $55(16.0)$ & $9(8.0)$ & $27(38.6)$ & $6(26.1)$ & $1(12.5)$ & \\
\hline
\end{tabular}

PTC; papillary thyroid carcinoma, FC; follicular carcinoma, MC; medullary carcinoma, PDC; poorly differentiated carcinoma, AC; anaplastic carcinoma, GLS1; glutaminase 1, GDH; glutamate dehydrogenase, ASCT2; amino acid transporter-2

Tumoral ASCT2 expression was higher in MC but lower in $\mathrm{FC}(\mathrm{p}<0.001)$.

The results of the correlation analysis of the expression of GLS1, GDH, and ASCT showed significant quantitative correlation between GDH and GLS1 $(r=0.364)$, between GDH and ASCT2 ( $r=0.174)$, between GLS1 and ASCT2 ( $r$ $=0.213)$, and between GDH(S) and GLS1(S) ( $\mathrm{r}=0.403$; all $\mathrm{p}<0.001$; Table 2). Furthermore, we performed a correlation analysis between the subtype of thyroid cancer with the expression of GLS1, GDH, and ASCT. As a result, in PTC, statistically significant correlation was shown between GLS1 and GDH $(\mathrm{r}=0.328, \mathrm{p}<0.001)$, between GLS1 and ASCT2 $(\mathrm{r}=0.251, \mathrm{p}<0.001)$, and between GDH and ASCT2 $(\mathrm{r}=0.165$, $\mathrm{p}=0.002$ ). The same result was also shown in $\mathrm{FC}$, with a significant correlation between GLS1 and GDH ( $\mathrm{r}=0.373$, $\mathrm{p}<0.001)$, between GLS1 and ASCT2 $(\mathrm{r}=0.246, \mathrm{p}=0.010)$, and between GDH and ASCT2 $(r=0.190, p=0.046)$. In addition, the correlation between GLS1 and GDH ( $\mathrm{r}=0.030$, $\mathrm{p}=0.012$ ) was shown in MC and between GLS1 and ASCT2 $(\mathrm{r}=0.476, \mathrm{p}=0.025)$ in PDC were noted.

\section{Expression of glutamine metabolism-related proteins according to the histologic subtype of thyroid cancer}

We investigated the expression of glutamine metabolism-related proteins according to the histologic subtype of thyroid cancer. First, in PTC, tumoral GLS1 and tumoral GDH expression was higher in the conventional type than in the follicular variant $(\mathrm{p}=0.024$ and $\mathrm{p}<$ 0.001 , respectively) (Figure 2 and Table 3 ). In addition, PTC with the BRAF V600E mutation showed higher expression of tumoral GLS1, tumoral GDH, and tumoral ASCT2 (p < 0.001) (Figure 3 and Table 3). Secondly, in follicular neoplasms, tumoral GLS1 and tumoral GDH expression was higher in FC than in FA $(p=0.021$ and 0.001, respectively) (Figure 4 and Table 4). Thirdly, in FC, the expression of glutamine metabolism-related proteins showed no significant difference between the minimally invasive type and the widely invasive type (Table 5).

\section{Correlation between the expression of glutamine metabolism-related proteins and clinicopathologic factors}

We investigated the correlation between the expression of glutamine metabolism-related proteins and the clinicopathologic factors in patients with thyroid cancer except for AC. Tumoral GDH positivity was associated with extrathyroidal extension, small tumor size, and lymph node metastasis $(\mathrm{p}<0.001$ for all). In PTC, the expression of tumoral GLS1 and tumoral GDH was associated with an infiltrative tumor margin $(\mathrm{p}=0.011$ and 0.002 , respectively) (Figure 5). 
Table 2: Correlation among the expressions of glutamine metabolism-related proteins

\begin{tabular}{|c|c|c|c|c|}
\hline Parameters & GLS1 & GDH & ASCT2 & GLS1 (S) \\
\hline \multicolumn{5}{|l|}{ GLS1 } \\
\hline \multicolumn{5}{|l|}{ Correlation coefficient } \\
\hline \multicolumn{5}{|l|}{ p-value } \\
\hline \multicolumn{5}{|l|}{ GDH } \\
\hline Correlation coefficient & 0.364 & & & \\
\hline p-value & $<0.001$ & & & \\
\hline \multicolumn{5}{|l|}{ ASCT2 } \\
\hline Correlation coefficient & 0.213 & 0.174 & & \\
\hline $\mathrm{p}$-value & $<0.001$ & $<0.001$ & & \\
\hline \multicolumn{5}{|l|}{ GLS1 (S) } \\
\hline Correlation coefficient & 0.066 & 0.035 & -0.034 & \\
\hline $\mathrm{p}$-value & 0.121 & 0.403 & 0.423 & \\
\hline \multicolumn{5}{|l|}{ GDH (S) } \\
\hline Correlation coefficient & 0.077 & 0.058 & 0.023 & 0.403 \\
\hline p-value & 0.068 & 0.170 & 0.580 & $<0.001$ \\
\hline
\end{tabular}

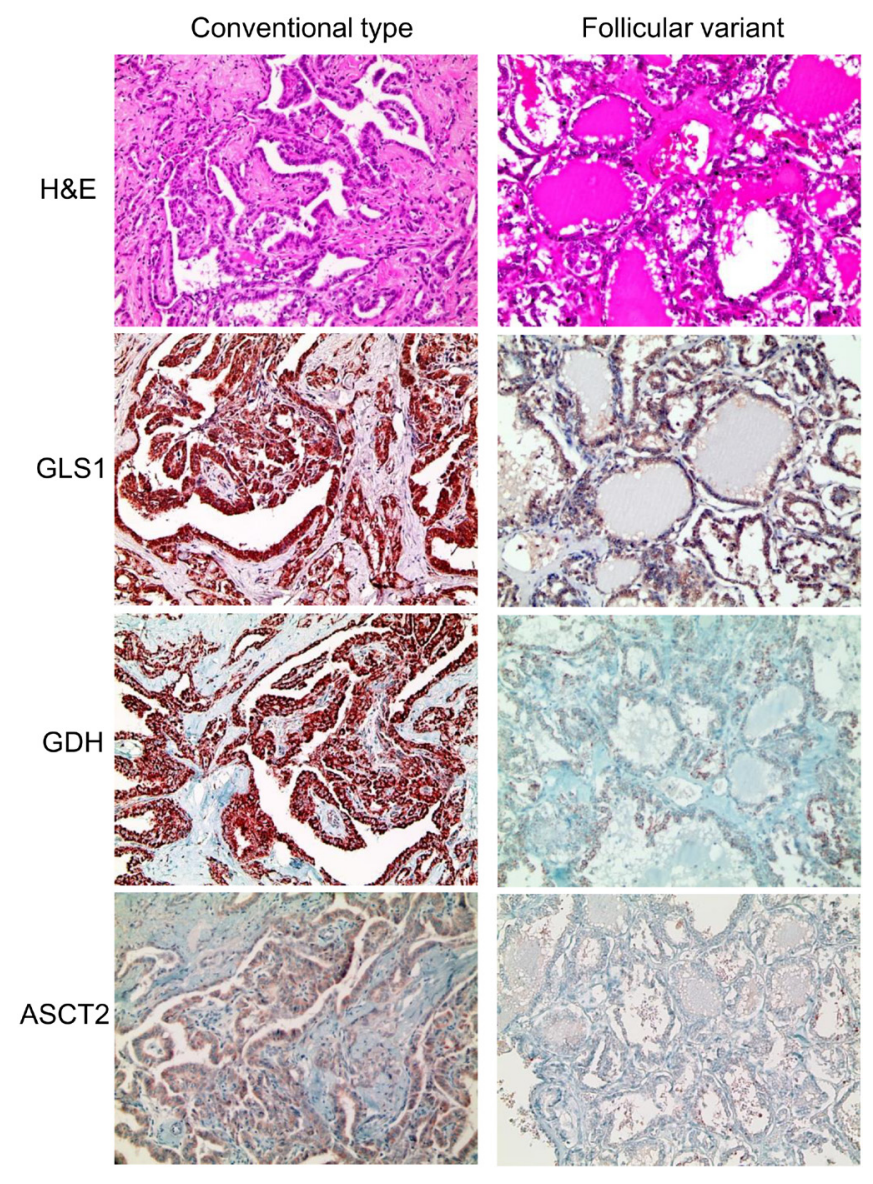

Figure 2: Expression of glutamine metabolism-related proteins according to the histologic subtype of papillary thyroid cancer (PTC). Tumoral GLS1 and tumoral GDH expression are higher in the conventional type of PTC than in the follicular variant of PTC. GLS1; glutaminase 1, GDH; glutamate dehydrogenase 
Table 3: Expression of glutamine metabolism-related proteins according to the histologic subtype and BRAF V600E mutation status of papillary thyroid carcinoma

\begin{tabular}{|c|c|c|c|c|c|c|c|}
\hline \multirow{2}{*}{ Parameters } & \multirow{2}{*}{$\begin{array}{c}\text { Total } \\
\mathrm{N}=344(\%)\end{array}$} & \multicolumn{2}{|c|}{ Histologic subtype } & \multirow{2}{*}{ p-value } & \multicolumn{2}{|c|}{$\begin{array}{l}\text { BRAF V600E mutation } \\
\text { status }\end{array}$} & \multirow{2}{*}{ p-value } \\
\hline & & $\begin{array}{c}\text { Conventional } \\
\text { type } \\
\text { n= } 304(\%)\end{array}$ & $\begin{array}{c}\text { Follicular } \\
\text { variant } \\
n=40(\%)\end{array}$ & & $\begin{array}{c}\text { No mutation } \\
n=106(\%)\end{array}$ & $\begin{array}{c}\text { Mutation } \\
n=238(\%)\end{array}$ & \\
\hline GLS1 (T) & & & & 0.024 & & & $<0.001$ \\
\hline Negative & $141(41.0)$ & $118(38.8)$ & $23(57.5)$ & & $58(54.7)$ & $83(34.9)$ & \\
\hline Positive & $203(59.0)$ & $186(61.2)$ & $17(42.5)$ & & $48(45.3)$ & $155(65.1)$ & \\
\hline GDH (T) & & & & $<0.001$ & & & $<0.001$ \\
\hline Negative & $43(12.5)$ & $28(9.2)$ & $15(37.5)$ & & $26(24.5)$ & $17(7.1)$ & \\
\hline Positive & $301(87.5)$ & $276(90.8)$ & $25(62.5)$ & & $80(75.5)$ & $221(92.9)$ & \\
\hline GDH (S) & & & & 1.000 & & & 0.246 \\
\hline Negative & $341(99.1)$ & $301(99.0)$ & $40(100.0)$ & & $106(100.0)$ & $235(98.7)$ & \\
\hline Positive & $3(0.9)$ & $3(1.0)$ & $0(0.0)$ & & $0(0.0)$ & $3(1.3)$ & \\
\hline $\operatorname{ASCT} 2(\mathrm{~T})$ & & & & 0.041 & & & $<0.001$ \\
\hline Negative & $289(84.0)$ & $251(82.6)$ & $38(95.0)$ & & $102(96.2)$ & $187(78.6)$ & \\
\hline Positive & $55(16.0)$ & $53(17.4)$ & $2(5.0)$ & & $4(3.8)$ & $51(21.4)$ & \\
\hline
\end{tabular}

GLS1; glutaminase 1, GDH; glutamate dehydrogenase, ASCT2; amino acid transporter-2

\section{Influence of the expression of glutamine metabolism-related proteins on patient prognosis}

We investigated the effect of the expression of glutamine metabolism-related proteins on prognosis through univariate analysis and multivariate Cox analysis. In univariate analysis, shorter disease-free survival was associated with stromal GDH expression $(\mathrm{p}<0.001)$ (Table 6). In multivariate Cox analysis, shorter diseasefree survival was associated with lymph node metastasis (hazard ratio: 6.021, 95\% confidence interval [CI]: $1.352-26.82, p=0.019)$, and shorter overall survival was associated with old age ( $\geq 45$ years, hazard ratio: 25.26 , 95\% CI: 3.047-209.4, $\mathrm{p}=0.003$ ), lymph node metastasis (hazard ratio: 4.466, 95\% CI: 1.352-14.76, $\mathrm{p}=0.014$ ) and stromal GDH positivity (hazard ratio: $21.48,95 \% \mathrm{CI}$ : 2.178-211.8, $\mathrm{p}=0.009$ ) (Table 7).

\section{DISCUSSION}

In this study, GLS1 and GDH showed higher expression in both tumor cells and stroma in AC, but it was lower in FC. In general, the higher tumor aggressiveness, the higher metabolic activity and glutamine metabolismrelated protein - GLS1, GDH, and ASCT2 - has been reported to be associated with tumor aggressive factor in other tumors [19-21]. There are several possible reasons for the higher expression of glutamine metabolism-related proteins in AC than in other subtypes: different tumor cell proliferative activity, high metastatic potential, and the impact of oncogenic driver. AC should show the highest metabolic activity, as metabolic activity was reported to be more than three times greater in $\mathrm{AC}$ than in other subtypes of thyroid cancer [22]. AC also has high metastatic potential, with distant metastasis reported at diagnosis in $46 \%$ of cases [23], and in tumor metastasis, glutamine metabolism has been reported to play an important role [24]. Finally, unlike other subtypes of thyroid cancer, AC has been shown to have increased HER-2 expression [25] and activation of Wnt $\beta$-catenin pathway [26]. HER-2 and $\beta$-catenin pathway have been reported to be associated with increased glutamine metabolism [27, 28].

One interesting point is that in PDC, a highly aggressive type of tumor similar to $\mathrm{AC}$, the expression of GLS1 and GDH was not significantly higher than that of other subtypes, unlike AC. The different expressions in $\mathrm{PDC}$ and $\mathrm{AC}$ can be explained by the genetic change between the two subtypes. In previous studies, one major difference was that TP53 mutation, which is known to be associated with metabolism, was shown in $26 \%$ of PDC samples as opposed to $60 \%$ of AC samples [29-31]. Glut-1 and Glut-4, key proteins in glycolysis, were reported to be inhibited by wild type p53 [32]. Considering that TP53 mutation neutralizes this interaction, AC was reported to exhibit TP53 and Glut-1 overexpression [33]. An 
association between TP53 mutation and metabolism was also shown, potentially explaining the different GLS1 and GDH expressions in PDC and AC in this study. Furthermore, p53 immunohistochemical staining was performed in PDC and AC to evaluate the association with the expressions of glutamine metabolism-related proteins. As a result, p53 positivity showed an association with stromal GDH expression $(p=0.029)$, tumoral GLS1 $(p=0.054)$, and stromal GLS1 $(p=0.055)$, further supporting the relationship between $\mathrm{p} 53$ positivity and the expressions of glutamine metabolism-related proteins (Supplementary Table 5). Further research using nextgeneration sequencing analyzed the genetic alterations between PDC and AC. As a result, several genetic changes were coincided in PDC and AC. However, each type has been reported as having its own specific genetic background [34].

In particular, the expression in $\mathrm{AC}$ was high in stroma as well as in tumor cells. In breast cancer, glutamine metabolism-related protein expression in

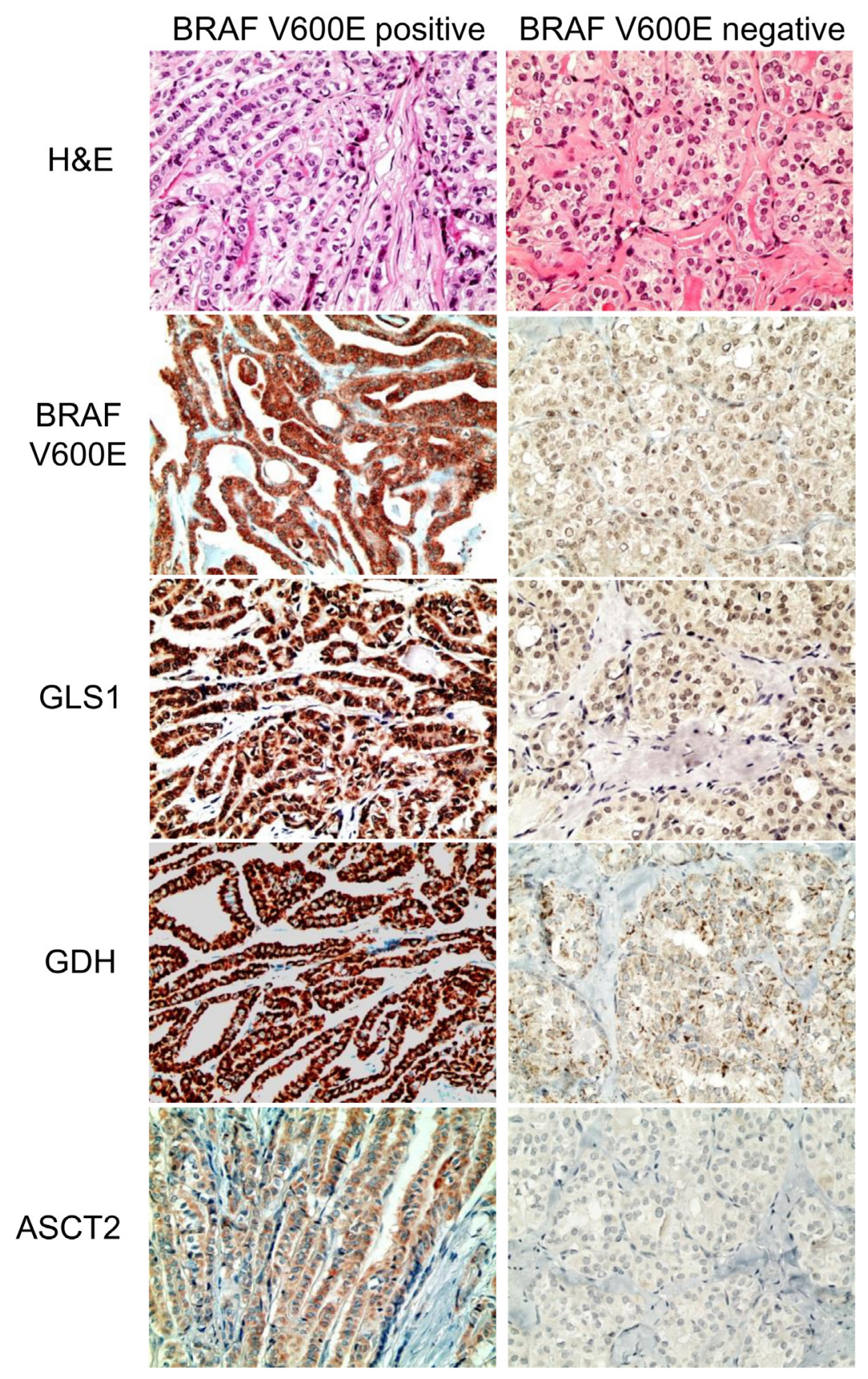

Figure 3: Expression of glutamine metabolism-related proteins according to the BRAF V600E mutation status in papillary thyroid cancer. Papillary thyroid cancer with the BRAF V600E mutation shows higher expression of tumoral GLS1, tumoral GDH, and tumoral ASCT2. GLS1; glutaminase 1, GDH; glutamate dehydrogenase, ASCT2; amino acid transporter-2 
stroma was similar to such expression in tumor cells [21]. Metabolic interaction could exist between tumoral and stromal cells, such as cancer-associated fibroblasts, according to the cancer types [7, 35-38]. In addition, the interaction has been reported to exist in glutamine metabolic pathway. Previous studies have shown a vicious cycle wherein ammonia (a byproduct of tumor cell glutaminolysis) diffuses into the stroma, induces autophagy, produces glutamine as a product of autophagy activity, and is passed back to tumor cells [5-9]. In one study, when the MCF-7 cell line was co-cultured with fibroblasts, the expression of GLS, GDH, and SLC6A14 (glutamine importer) in tumor cells increased and glutamine neosynthesis decreased compared to when the cell line was cultured alone. The transmission of glutamine from stromal cells to tumor cells has demonstrated, and in the case, the cell proliferation has reported to be increased [9]. Therefore, the interaction between tumor cells and stromal cells in the glutamine metabolic pathway promotes tumor cell proliferation and growth. The increased glutamine metabolic activity in tumor cells and stromal cells in AC contributes to tumor aggressiveness. In addition, tumoral GLS1 and GDH expression was the highest in conventional type PTC followed by follicular variant PTC, FC, and FA; therefore, GLS1 and GDH were proven to show lower expression with more follicular differentiation. As the expression of metabolic pathwayrelated protein such as Glut-1 has been reported to be

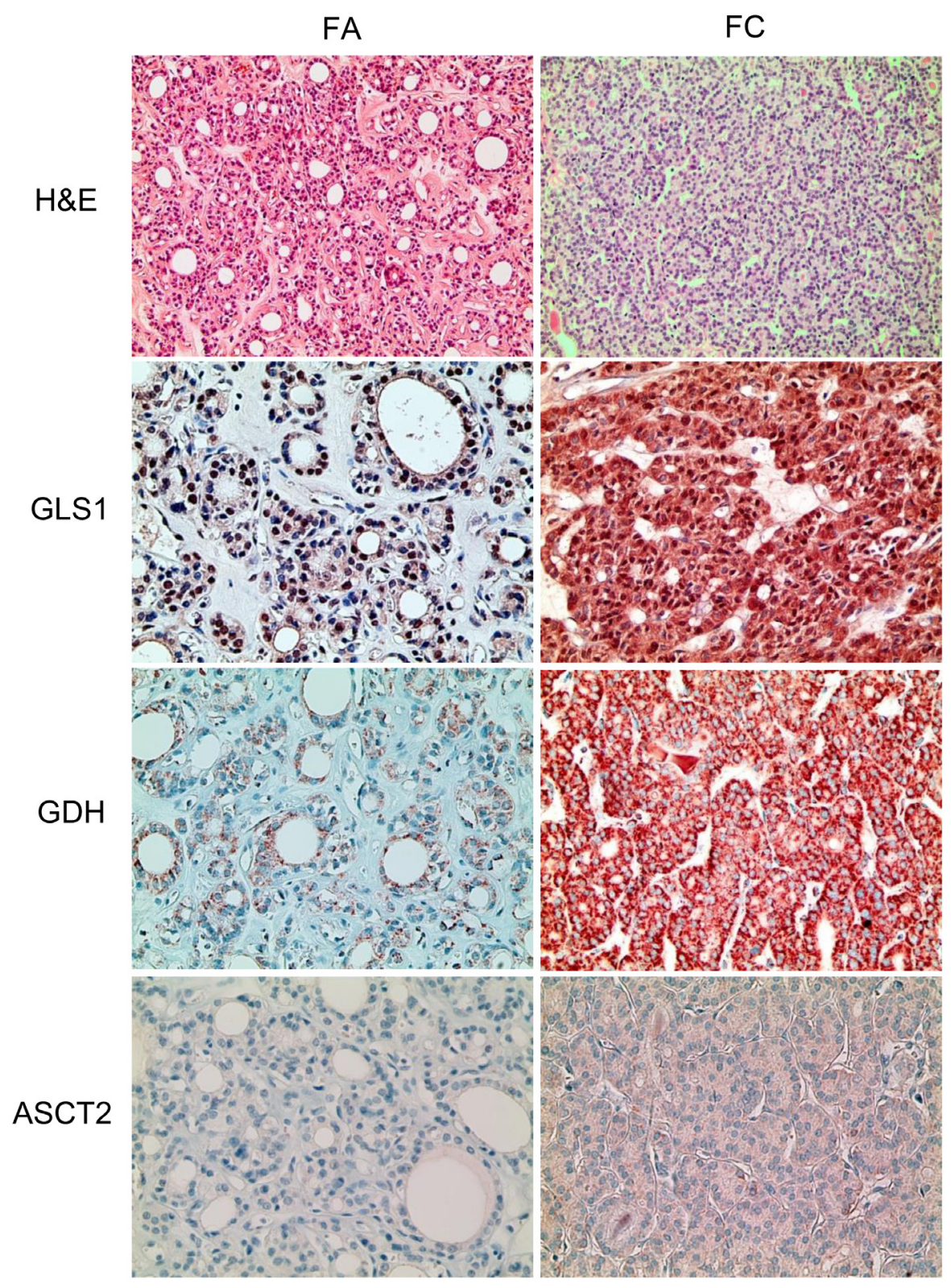

Figure 4: Expression of glutamine metabolism-related proteins in follicular neoplasms. Tumoral GLS1 and tumoral GDH expression are higher in follicular carcinoma than in follicular adenoma. GLS1; glutaminase 1, GDH; glutamate dehydrogenase 
Table 4: Expression of glutamine metabolism-related proteins in follicular neoplasms

\begin{tabular}{|c|c|c|c|c|}
\hline Parameters & $\begin{array}{c}\text { Total } \\
\mathrm{N}=264(\%)\end{array}$ & $\begin{array}{c}\text { FA } \\
n=152(\%)\end{array}$ & $\begin{array}{c}\text { FC } \\
n=112(\%)\end{array}$ & p-value \\
\hline GLS1 (T) & & & & 0.021 \\
\hline Negative & $185(70.1)$ & $115(75.7)$ & $70(62.5)$ & \\
\hline Positive & 79 (29.9) & $37(24.3)$ & $42(37.5)$ & \\
\hline GDH (T) & & & & 0.001 \\
\hline Negative & $144(54.5)$ & $96(63.2)$ & 48 (42.9) & \\
\hline Positive & $120(45.5)$ & $56(36.8)$ & $64(57.1)$ & \\
\hline ASCT2 (T) & & & & 0.156 \\
\hline Negative & $249(94.3)$ & $146(96.1)$ & $103(92.0)$ & \\
\hline Positive & $15(5.7)$ & $6(3.9)$ & $9(8.0)$ & \\
\hline
\end{tabular}

FA; follicular adenoma, FC: follicular carcinoma, GLS1; glutaminase 1, GDH; glutamate dehydrogenase, ASCT2; amino acid transporter-2

Table 5: Expression of glutamine metabolism-related proteins according to the histologic subtype of follicular carcinoma (FC)

\begin{tabular}{|c|c|c|c|c|}
\hline Parameters & $\begin{array}{c}\text { Total } \\
\text { N=112 }(\%)\end{array}$ & $\begin{array}{c}\text { FC, minimally } \\
\text { invasive type } \\
\text { n=99 }(\%)\end{array}$ & $\begin{array}{c}\text { FC, widely invasive } \\
\text { type } \\
\text { n=13 }(\%)\end{array}$ & p-value \\
\hline GLS1 (T) & & & & 0.493 \\
\hline Negative & $70(62.5)$ & $63(63.6)$ & $7(53.8)$ & \\
\hline Positive & $42(37.5)$ & $36(36.4)$ & $6(46.2)$ & \\
\hline GDH (T) & & & & 0.394 \\
\hline Negative & 48 (42.9) & $41(41.4)$ & $7(53.8)$ & \\
\hline Positive & $64(57.1)$ & $58(58.6)$ & $6(46.2)$ & \\
\hline $\operatorname{ASCT} 2(\mathrm{~T})$ & & & & 0.257 \\
\hline Negative & $103(92.0)$ & $90(90.9)$ & $13(100.0)$ & \\
\hline Positive & $9(8.0)$ & $9(9.1)$ & $0(0.0)$ & \\
\hline
\end{tabular}

FC: follicular carcinoma, GLS1; glutaminase 1, GDH; glutamate dehydrogenase, ASCT2; amino acid transporter-2

different according to tumor differentiation in various human cancers $[39,40]$, such a phenomenon in thyroid cancer can seem possible.

PTC with the BRAF V600E mutation showed a higher expression of glutamine metabolism-related proteins. The BRAF V600E mutation is associated with extra-thyroidal extension, advanced TNM stage, lymph node metastasis, multifocality, and recurrence in a metaanalysis study [41]. Because PTC with the BRAF V600E mutation has aggressive tumor biology, it can be suggested that it shows higher expression of glutamine metabolismrelated proteins. In addition, PTC with the BRAF V600E mutation has been reported to show increased glucose metabolism [42]. One possible mechanism is that the BRAF mutation is associated with the activation of mitogen-activated protein kinase downstream molecules such as c-MYC and HIF-1a; therefore, glucose metabolism increases. Furthermore, cell proliferation in melanoma cells with BRAF mutations has been reported to rely on glutamine metabolism [43]. Accordingly, the association between PTC with the BRAF V600E mutation and increased glutamine metabolism is supported.

The expression of ASCT2 was higher in MC. The association with the $M Y C$ gene can be considered a possible mechanism. In previous studies, MYC expression has been reported in MC [44-46]. The $M Y C$ gene has been 
reported to increase the expression of ASCT2 by binding to the promoter element of the glutamine transporter [47]; hence, the higher ASCT2 expression in MC can be explained.

Stromal GDH expression was an independent prognostic factor in thyroid cancer. In previous studies, GDH expression was shown to be associated with poor prognosis in colon cancer [48], carcinoma of unknown primary [49], and breast phyllodes tumor [20]. The compartment with GDH expression differed depending on the tumor. Stromal GDH expression in breast phyllodes tumors [20] and tumoral GDH expression in carcinoma of unknown primary [49] have been reported to be associated with patient prognosis. An analysis of colon cancer did not divide the compartment between tumor cells and stroma; therefore, GDH expression could not be evaluated in this case [48]. Likewise, the influence of GDH on prognosis differs according to the expressed compartments.

In this study, we showed positive correlation between the expression of GLS1, GDH and ASCT2. This positive correlation was observed when targeting not only all subtypes of thyroid cancer but also PTC and FC and a partial correlation was also shown in MC and PDC. It suggests the role of GLS1, GDH, and ASCT2 evaluation by immunohistochemical staining could possibly reflect the glutamine metabolism activity.

The results suggest that the glutamine metabolism pathway can be used as a possible target for therapy in thyroid cancer. The potential candidates for target therapy among thyroid cancer are radioiodine refractory differentiated thyroid cancer, PDC, AC, and MC. Targeted therapies that is currently used in thyroid cancer are tyrosine kinase inhibitors (TKIs) and monoclonal antibodies (mAbs), which inhibits the tyrosine kinase activity that is essential in the pathogenesis of thyroid cancer [50]. However, clinical trials regarding TKIs and $\mathrm{mAbs}$ had shown unsatisfactory results, only with a partial response rate ranging from 2 to $45 \%$ [51-54]. This might be attributable by the drug resistance, cytostatic action of TKIs and drug toxicity [50], necessitating novel target agent to overcome these limitations. The possible strategy is to reduce glutamine metabolic enzyme activity or reduce glutamine uptake. GLS1 inhibitors including BPTES [55-57], 968 [58-60], and CB-839 [61, 62] are under preclinical and clinical trials for the treatment of various tumors. BenSer as an ASCT2 inhibitor has been reported to inhibit the proliferation of melanoma cells [63]. In particular, radioiodine refractory thyroid tumor might be suitable for targeted therapy since it shows positive scan in 18FDG-PET [64]. Therefore, the inhibition of metabolic pathway might be used as an alternative effective therapeutic option, which requires further studies.

In conclusion, the expression of glutamine metabolism-related proteins in thyroid cancer was found to differ according to histologic subtype. GLS1 and GDH expression was high in both tumor cells and stroma of AC.
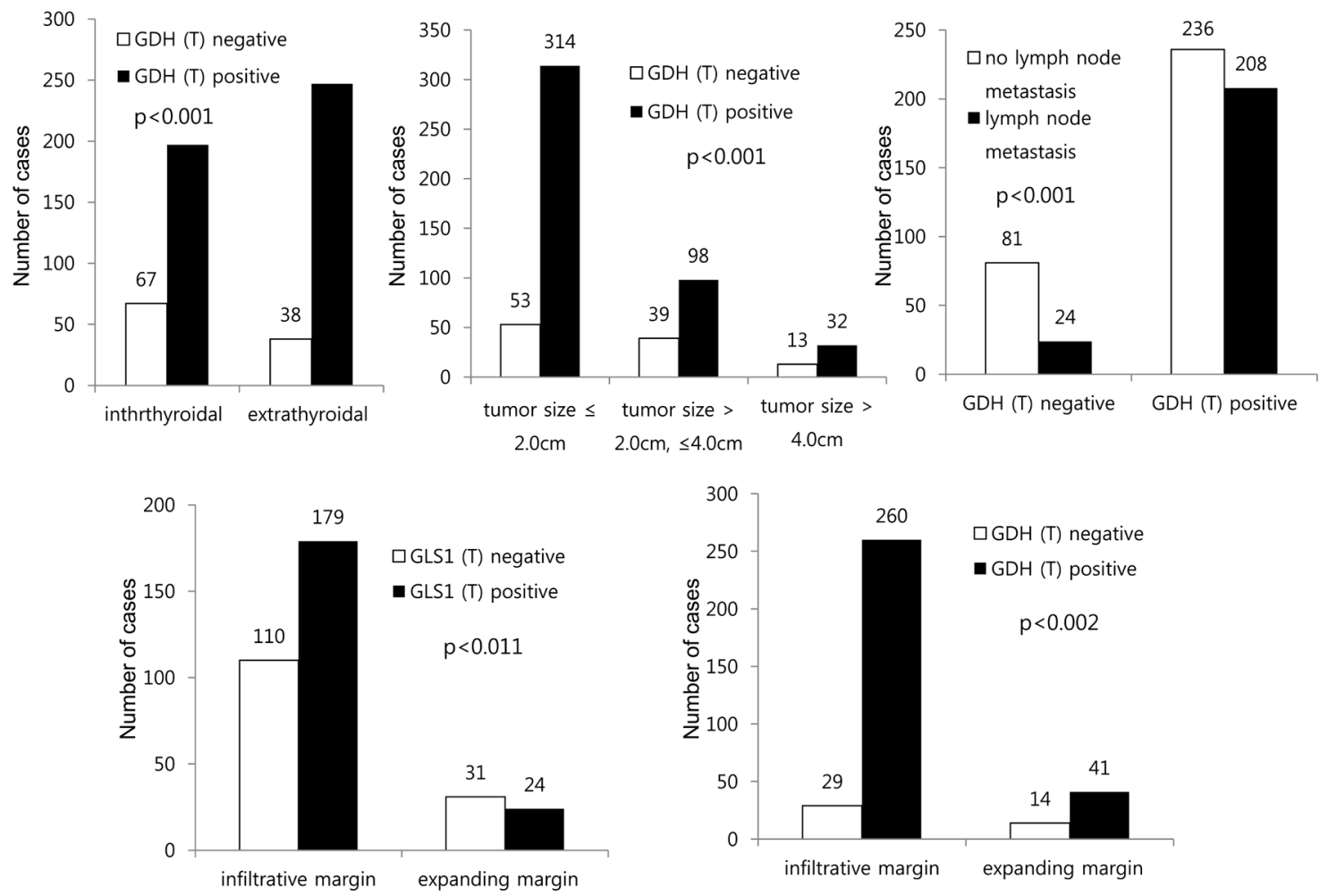

Figure 5: Correlation between the expressions of glutamine metabolism-related proteins and clinicopathologic factors in thyroid cancer and papillary thyroid carcinoma. 
Table 6: Univariate analysis of the influence of glutamine-related protein expression in thyroid cancer on disease-free and overall survival by the log-rank test

\begin{tabular}{|c|c|c|c|c|c|}
\hline \multirow{2}{*}{ Parameter } & \multirow{2}{*}{$\begin{array}{c}\text { Number of } \\
\text { patients*/ } \\
\text { recurrence/death }\end{array}$} & \multicolumn{2}{|c|}{ Disease-free survival } & \multicolumn{2}{|c|}{ Overall survival } \\
\hline & & $\begin{array}{l}\text { Mean survival } \\
(95 \% \text { CI) months }\end{array}$ & $P$-value & $\begin{array}{l}\text { Mean survival } \\
(95 \% \text { CI) months }\end{array}$ & $P$-value \\
\hline GLS1 (T) & & & 0.141 & & 0.938 \\
\hline Negative & $247 / 22 / 13$ & $101(98-105)$ & & $106(103-108)$ & \\
\hline Positive & $302 / 17 / 17$ & $106(103-108)$ & & $106(103-108)$ & \\
\hline GDH (T) & & & 0.470 & & 0.896 \\
\hline Negative & $105 / 9 / 5$ & $101(96-107)$ & & $106(103-110)$ & \\
\hline Positive & $444 / 30 / 25$ & $104(102-107)$ & & $106(104-108)$ & \\
\hline GDH (S) & & & 0.110 & & $<0.001$ \\
\hline Negative & $545 / 38 / 28$ & $104(102-106)$ & & $107(105-108)$ & \\
\hline Positive & $4 / 1 / 2$ & $68(24-112)$ & & $54(13-95)$ & \\
\hline $\operatorname{ASCT} 2(\mathrm{~T})$ & & & 0.677 & & 0.217 \\
\hline Negative & $452 / 33 / 22$ & $104(101-106)$ & & $107(105-109)$ & \\
\hline Positive & $97 / 6 / 8$ & $103(98-108)$ & & $102(96-107)$ & \\
\hline
\end{tabular}

*cases of AC were excluded. GLS1; glutaminase 1, GDH; glutamate dehydrogenase, ASCT2; amino acid transporter-2

Table 7: Multivariate analysis of factors influencing survival of patients with thyroid cancer *

\begin{tabular}{|c|c|c|c|c|c|c|}
\hline \multirow[b]{2}{*}{ Included parameters } & \multicolumn{3}{|c|}{ Disease-free survival } & \multicolumn{3}{|c|}{ Overall survival } \\
\hline & $\begin{array}{c}\text { Hazard } \\
\text { ratio }\end{array}$ & $95 \% \mathrm{CI}$ & $P$-value & $\begin{array}{c}\text { Hazard } \\
\text { ratio }\end{array}$ & $95 \% \mathrm{CI}$ & $P$-value \\
\hline Age (years) & & & 0.631 & & & 0.003 \\
\hline$<45$ versus $\geq 45$ & 1.263 & $0.488-3.272$ & & 25.26 & $3.047-209.4$ & \\
\hline Sex & & & 0.668 & & & 0.402 \\
\hline Male versus Female & 1.265 & $0.433-3.690$ & & 1.564 & $0.550-4.449$ & \\
\hline Tumor size $(\mathrm{cm})$ & & & 0.798 & & & 0.402 \\
\hline$\leq 2.0$ versus $>2.0$ & 1.147 & $0.400-3.288$ & & 1.564 & $0.550-4.449$ & \\
\hline Tumor extension & & & 0.352 & & & 0.504 \\
\hline Intrathyroidal versus Extrathyroidal & 0.631 & $0.239-1.663$ & & 0.688 & $0.229-2.061$ & \\
\hline LN metastasis & & & 0.019 & & & 0.014 \\
\hline No versus Yes & 6.021 & $1.352-26.82$ & & 4.466 & $1.352-14.76$ & \\
\hline GLS1 (T) & & & 0.273 & & & 0.422 \\
\hline Negative versus positive & 0.587 & $0.226-1.522$ & & 0.676 & $0.261-1.757$ & \\
\hline GDH (S) & & & $\mathrm{n} / \mathrm{a}$ & & & 0.009 \\
\hline Negative versus positive & $\mathrm{n} / \mathrm{a}$ & $\mathrm{n} / \mathrm{a}$ & & 21.48 & $2.178-211.8$ & \\
\hline
\end{tabular}

*cases of AC were excluded. GLS1; glutaminase 1, GDH; glutamate dehydrogenase 
ASCT2 expression was high in MC. In addition, tumoral GLS1 and tumoral GDH expression was high in PTC with the $B R A F \mathrm{~V} 600 \mathrm{E}$ mutation. Therefore, the glutamine metabolism pathway may be a possible target for therapy in thyroid cancer.

\section{MATERIALS AND METHODS}

\section{Patient selection}

For PTC, we included patients who underwent surgery at Severance Hospital between January 2012 and December 2013. For other subtypes, we included patients who underwent surgery at Severance Hospital between January 2000 and December 2014. Patients treated with neoadjuvant chemotherapy were excluded. This study was approved by the Institutional Review Board (IRB) of Yonsei University Severance Hospital. Consent forms of patients were exempt by IRB. All cases were retrospectively reviewed by a thyroid pathologist (Koo JS), and histologic review was performed by using hematoxylin and eosin-stained slides. Clinicopathologic data were obtained from the patients' medical records; they included age at diagnosis, disease recurrence, metastasis, current status, and length of follow-up. The tumor size, tumor margin (infiltrative or expanding), extent (confined to the thyroid parenchyma or with extrathyroidal spread), and the status of metastatic lymph nodes were also noted from review of the slides and the surgical pathology reports.

\section{Tissue microarray analysis}

Representative areas were selected on hematoxylineosin-stained slides, and the corresponding spot was marked on the surface of the matching paraffin block. Core biopsies $(3 \mathrm{~mm})$ were taken from selected areas and placed into a $6 \times 5$ recipient block. Two tissue cores were extracted from each case to minimize extraction bias. Each tissue core was assigned a unique tissue microarray location number that was linked to a database containing other clinicopathologic data.

\section{Immunohistochemistry}

Antibodies used for immunohistochemistry are listed in Supplementary Table 1. All immunohistochemistry was performed on formalin-fixed, paraffin-embedded tissue sections by using an automatic immunohistochemistry staining device (Benchmark XT, Ventana Medical System, Tucson, AZ, USA). Briefly, 5- $\mu$ m-thick formaldehydefixed paraffin-embedded tissue sections were transferred onto adhesive slides and dried at $62^{\circ} \mathrm{C}$ for 30 minutes. Standard heat epitope retrieval was performed for 30 minutes in ethylene diamine tetraacetic acid, $\mathrm{pH} 8.0$, in the autostainer. The samples were then incubated with primary antibodies. After incubation with primary antibodies, the sections were subsequently incubated with biotinylated anti-mouse immunoglobulins, peroxidaselabeled streptavidin (LSAB kit, DakoCytomation), and 3,3'-diaminobenzidine. Negative control samples were processed without the primary antibody. Positive control tissue was used as per the manufacturer's recommendation. All slides were counterstained with Harris hematoxylin.

\section{Interpretation of immunohistochemical staining}

Immunohistochemical markers were assessed under light microscopy with x200 magnification in the entire core of the tissue microarray. The expression of glutamine metabolism-related proteins was evaluated semi-quantitatively according to a previously reported method [65]. Tumoral and stromal staining was assessed as 0 : negative or weak immunostaining in $<1 \%$ of the tumor/stroma, 1: focal expression in $1-10 \%$ of the tumor/ stroma, 2 : positive in $11 \%-50 \%$ of the tumor/stroma, and 3 : positive in $51 \%-100 \%$ of the tumor/stroma. The score of $\geq 2$ was defined as positive. BRAF V600E staining was considered positive when more than $20 \%$ tumor cells were positive [66]. Immunohistochemical staining was interpreted independently by two pathologists (KHM and KJS). In cases of discrepancy between the pathologists, the final result was determined through discussion under the multi-view microscopy.

\section{Statistical analysis}

Data were analyzed using SPSS for Windows, Version 12.0 (SPSS Inc., Chicago, IL, USA). For determination of statistical significance, the Student $t$ test and Fisher exact tests were used for continuous and categorical variables, respectively. The correlation between the expression of GLS1, GDH, and ASCT was analyzed using Kendall's method. In the case of analyzing data with multiple comparisons, a corrected p-value with the application of the Bonferroni multiple comparison procedure was used. Statistical significance was set at $\mathrm{p}<$ 0.05. Kaplan-Meier survival curves and log-rank statistics were employed to evaluate time to tumor recurrence and overall survival. Multivariate regression analysis was performed using the Cox proportional hazards model.

\section{ACKNOWLEDGMENTS}

This study was supported by a grant from the National R\&D Program for Cancer Control, Ministry of Health \& Welfare, Republic of Korea (1420080). This research was supported by Basic Science Research Program through the National Research Foundation of Korea (NRF) funded by the Ministry of Science, ICT and Future Planning (2015R1A1A1A05001209). 


\section{CONFLICTS OF INTEREST}

No competing financial interests exist.

\section{REFERENCES}

1. Warburg O. On the origin of cancer cells. Science. 1956; 123:309-314.

2. DeBerardinis RJ, Cheng T. Q's next: the diverse functions of glutamine in metabolism, cell biology and cancer. Oncogene. 2010; 29:313-324

3. Collins CL, Wasa M, Souba WW, Abcouwer SF. Regulation of glutamine synthetase in human breast carcinoma cells and experimental tumors. Surgery. 1997; 122:451-463; discussion 463-454.

4. Friday E, Oliver R, 3rd, Welbourne T, Turturro F. Glutaminolysis and glycolysis regulation by troglitazone in breast cancer cells: Relationship to mitochondrial membrane potential. J Cell Physiol. 2011; 226:511-519.

5. Marino G, Kroemer G. Ammonia: A Diffusible Factor Released by Proliferating Cells That Induces Autophagy. Sci Signal. 2010; 3.

6. Eng $\mathrm{CH}$, Abraham RT. Glutaminolysis yields a metabolic by-product that stimulates autophagy. Autophagy. 2010; 6:968-970

7. Martinez-Outschoorn UE, Pavlides S, Howell A, Pestell RG, Tanowitz HB, Sotgia F, Lisanti MP. Stromal-epithelial metabolic coupling in cancer: integrating autophagy and metabolism in the tumor microenvironment. The international journal of biochemistry \& cell biology. 2011; 43:1045-1051.

8. Pavlides S, Tsirigos A, Migneco G, Whitaker-Menezes D, Chiavarina B, Flomenberg N, Frank PG, Casimiro MC, Wang C, Pestell RG, Martinez-Outschoorn UE, Howell A, Sotgia F, Lisanti MP. The autophagic tumor stroma model of cancer: Role of oxidative stress and ketone production in fueling tumor cell metabolism. Cell Cycle. 2010; 9:3485-3505.

9. Ko YH, Lin Z, Flomenberg N, Pestell RG, Howell A, Sotgia F, Lisanti MP, Martinez-Outschoorn UE. Glutamine fuels a vicious cycle of autophagy in the tumor stroma and oxidative mitochondrial metabolism in epithelial cancer cells: Implications for preventing chemotherapy resistance. Cancer Biol Ther. 2011; 12.

10. McGivan JD, Bungard CI. The transport of glutamine into mammalian cells. Frontiers in bioscience. 2007; $12: 874-882$

11. Curthoys NP, Watford M. Regulation of glutaminase activity and glutamine metabolism. Annual review of nutrition. 1995; 15:133-159.

12. Dang CV. Glutaminolysis: supplying carbon or nitrogen or both for cancer cells? Cell Cycle. 2010; 9:3884-3886.

13. Stewart BW, Kleihues P. World Cancer Report 2003. Lyon.
14. Sherman SI. Thyroid carcinoma. Lancet (London, England). 2003; 361:501-511.

15. Choi J, Kim do H, Jung WH, Koo JS. Metabolic interaction between cancer cells and stromal cells according to breast cancer molecular subtype. Breast cancer research. 2013; 15:R78.

16. Kim SK, Jung WH, Koo JS. Differential expression of enzymes associated with serine/glycine metabolism in different breast cancer subtypes. PloS one. 2014; 9:e101004.

17. Kim YH, Jung WH, Koo JS. Expression of metabolismrelated proteins in invasive lobular carcinoma: comparison to invasive ductal carcinoma. Tumour biology. 2014; 35:10381-10393.

18. Yoon JK, Kim do H, Koo JS. Implications of differences in expression of sarcosine metabolism-related proteins according to the molecular subtype of breast cancer. Journal of translational medicine. $2014 ; 12: 149$.

19. Huang F, Zhang Q, Ma H, Lv Q, Zhang T. Expression of glutaminase is upregulated in colorectal cancer and of clinical significance. International journal of clinical and experimental pathology. 2014; 7:1093-1100.

20. Kim S, Jung WH, Koo JS. The expression of glutaminemetabolism-related proteins in breast phyllodes tumors. Tumour biology. 2013; 34:2683-2689.

21. Kim S, Kim do H, Jung WH, Koo JS. Expression of glutamine metabolism-related proteins according to molecular subtype of breast cancer. Endocrine-related cancer. 2013; 20:339-348.

22. Erickson LA, Jin L, Wollan PC, Thompson GB, van Heerden J, Lloyd RV. Expression of p27kip1 and Ki-67 in benign and malignant thyroid tumors. Modern pathology. 1998; 11:169-174.

23. McIver B, Hay ID, Giuffrida DF, Dvorak CE, Grant CS, Thompson GB, van Heerden JA, Goellner JR. Anaplastic thyroid carcinoma: a 50-year experience at a single institution. Surgery. 2001; 130:1028-1034

24. Chen J, Lee HJ, Wu X, Huo L, Kim SJ, Xu L, Wang Y, He J, Bollu LR, Gao G, Su F, Briggs J, Liu X, Melman T, Asara JM, Fidler IJ, et al. Gain of glucose-independent growth upon metastasis of breast cancer cells to the brain. Cancer research. 2015; 75:554-565.

25. Murakawa T, Tsuda H, Tanimoto T, Tanabe T, Kitahara S, Matsubara O. Expression of KIT, EGFR, HER-2 and tyrosine phosphorylation in undifferentiated thyroid carcinoma: implication for a new therapeutic approach. Pathology international. 2005; 55:757-765.

26. Oyen WJ, Bodei L, Giammarile F, Maecke HR, Tennvall J, Luster M, Brans B. Targeted therapy in nuclear medicinecurrent status and future prospects. Annals of oncology. 2007; 18:1782-1792.

27. Cadoret A, Ovejero C, Terris B, Souil E, Levy L, Lamers WH, Kitajewski J, Kahn A, Perret C. New targets of betacatenin signaling in the liver are involved in the glutamine metabolism. Oncogene. 2002; 21:8293-8301. 
28. Youngblood VM, Kim LC, Edwards DN, Hwang Y, Santapuram PR, Stirdivant SM, Lu P, Ye F, BrantleySieders DM, Chen J. The Ephrin-A1/EPHA2 Signaling Axis Regulates Glutamine Metabolism in HER2-Positive Breast Cancer. Cancer research. 2016.

29. Donghi R, Longoni A, Pilotti S, Michieli P, Della Porta G, Pierotti MA. Gene p53 mutations are restricted to poorly differentiated and undifferentiated carcinomas of the thyroid gland. The Journal of clinical investigation. 1993; 91:1753-1760.

30. Fagin JA, Matsuo K, Karmakar A, Chen DL, Tang SH, Koeffler HP. High prevalence of mutations of the p53 gene in poorly differentiated human thyroid carcinomas. The Journal of clinical investigation. 1993; 91:179-184.

31. Ito $T$, Seyama $T$, Mizuno $T$, Tsuyama N, Hayashi $T$, Hayashi Y, Dohi K, Nakamura N, Akiyama M. Unique association of $\mathrm{p} 53$ mutations with undifferentiated but not with differentiated carcinomas of the thyroid gland. Cancer research. 1992; 52:1369-1371.

32. Schwartzenberg-Bar-Yoseph F, Armoni M, Karnieli E. The tumor suppressor p53 down-regulates glucose transporters GLUT1 and GLUT4 gene expression. Cancer research. 2004; 64:2627-2633.

33. Kim YW, Do IG, Park YK. Expression of the GLUT1 glucose transporter, p63 and p53 in thyroid carcinomas. Pathology, research and practice. 2006; 202:759-765.

34. Sykorova V, Dvorakova S, Vcelak J, Vaclavikova E, Halkova T, Kodetova D, Lastuvka P, Betka J, Vlcek P, Reboun M, Katra R, Bendlova B. Search for new genetic biomarkers in poorly differentiated and anaplastic thyroid carcinomas using next generation sequencing. Anticancer research. 2015; 35:2029-2036.

35. Bonuccelli G, Tsirigos A, Whitaker-Menezes D, Pavlides S, Pestell RG, Chiavarina B, Frank PG, Flomenberg N, Howell A, Martinez-Outschoorn UE, Sotgia F, Lisanti MP. Ketones and lactate "fuel" tumor growth and metastasis: Evidence that epithelial cancer cells use oxidative mitochondrial metabolism. Cell Cycle. 2010; 9:3506-3514.

36. Martinez-Outschoorn UE, Balliet RM, Rivadeneira DB, Chiavarina B, Pavlides S, Wang C, Whitaker-Menezes D, Daumer KM, Lin Z, Witkiewicz AK, Flomenberg N, Howell A, Pestell RG, Knudsen ES, Sotgia F, Lisanti MP. Oxidative stress in cancer associated fibroblasts drives tumor-stroma co-evolution: A new paradigm for understanding tumor metabolism, the field effect and genomic instability in cancer cells. Cell Cycle. 2010; 9:3256-3276.

37. Pavlides S, Tsirigos A, Vera I, Flomenberg N, Frank PG, Casimiro MC, Wang C, Fortina P, Addya S, Pestell RG, Martinez-Outschoorn UE, Sotgia F, Lisanti MP. Loss of stromal caveolin-1 leads to oxidative stress, mimics hypoxia and drives inflammation in the tumor microenvironment, conferring the "reverse Warburg effect": a transcriptional informatics analysis with validation. Cell Cycle. 2010; 9:2201-2219.
38. Pavlides S, Whitaker-Menezes D, Castello-Cros R, Flomenberg N, Witkiewicz AK, Frank PG, Casimiro MC, Wang C, Fortina P, Addya S, Pestell RG, MartinezOutschoorn UE, Sotgia F, Lisanti MP. The reverse Warburg effect: aerobic glycolysis in cancer associated fibroblasts and the tumor stroma. Cell Cycle. 2009; 8:3984-4001.

39. Kato H, Takita J, Miyazaki T, Nakajima M, Fukai Y, Masuda N, Fukuchi M, Manda R, Ojima H, Tsukada $\mathrm{K}$, Kuwano H. Glut-1 glucose transporter expression in esophageal squamous cell carcinoma is associated with tumor aggressiveness. Anticancer research. 2002; 22:2635-2639.

40. Tateishi U, Yamaguchi U, Seki K, Terauchi T, Arai Y, Hasegawa T. Glut-1 expression and enhanced glucose metabolism are associated with tumour grade in bone and soft tissue sarcomas: a prospective evaluation by $[18 \mathrm{~F}]$ fluorodeoxyglucose positron emission tomography. European journal of nuclear medicine and molecular imaging. 2006; 33:683-691.

41. Liu X, Yan K, Lin X, Zhao L, An W, Wang C, Liu X. The association between BRAF (V600E) mutation and pathological features in PTC. European archives of otorhino-laryngology. 2014; 271:3041-3052.

42. Nagarajah J, Ho AL, Tuttle RM, Weber WA, Grewal RK. Correlation of BRAFV600E Mutation and Glucose Metabolism in Thyroid Cancer Patients: An (1)(8)F-FDG PET Study. Journal of nuclear medicine. 2015; 56:662-667.

43. Baenke F, Chaneton B, Smith M, Van Den Broek N, Hogan K, Tang H, Viros A, Martin M, Galbraith L, Girotti MR, Dhomen N, Gottlieb E, Marais R. Resistance to BRAF inhibitors induces glutamine dependency in melanoma cells. Molecular oncology. 2015.

44. Boultwood J, Wyllie FS, Williams ED, Wynford-Thomas D. $\mathrm{N}$-myc expression in neoplasia of human thyroid C-cells. Cancer research. 1988; 48:4073-4077.

45. Roncalli M, Viale G, Grimelius L, Johansson H, Wilander E, Alfano RM, Springall D, Battezzati PM, Polak JM, Coggi G. Prognostic value of N-myc immunoreactivity in medullary thyroid carcinoma. Cancer. 1994; 74:134-141.

46. Wang DG, Liu WH, Johnston CF, Sloan JM, Buchanan KD. Bcl-2 and c-Myc, but not bax and p53, are expressed during human medullary thyroid tumorigenesis. The American journal of pathology. 1998; 152:1407-1413.

47. Ren P, Yue M, Xiao D, Xiu R, Gan L, Liu H, Qing G. ATF4 and N-Myc coordinate glutamine metabolism in MYCNamplified neuroblastoma cells through ASCT2 activation. The Journal of pathology. 2015; 235:90-100.

48. Liu G, Zhu J, Yu M, Cai C, Zhou Y, Yu M, Fu Z, Gong Y, Yang B, Li Y, Zhou Q, Lin Q, Ye H, Ye L, Zhao X, Li $\mathrm{Z}$, et al. Glutamate dehydrogenase is a novel prognostic marker and predicts metastases in colorectal cancer patients. Journal of translational medicine. 2015; 13:144.

49. Kim HM, Kim do H, Jung WH, Koo JS. Metabolic phenotypes in primary unknown metastatic carcinoma. Journal of translational medicine. 2014; 12:2. 
50. Viola D, Valerio L, Molinaro E, Agate L, Bottici V, Biagini A, Lorusso L, Cappagli V, Pieruzzi L, Giani C, Sabini E, Passannati P, Puleo L, Matrone A, Pontillo-Contillo B, Battaglia V, et al. Treatment of advanced thyroid cancer with targeted therapies: ten years of experience. Endocrinerelated cancer. 2016; 23:R185-205.

51. Leboulleux S, Bastholt L, Krause T, de la Fouchardiere C, Tennvall J, Awada A, Gomez JM, Bonichon F, Leenhardt L, Soufflet C, Licour M, Schlumberger MJ. Vandetanib in locally advanced or metastatic differentiated thyroid cancer: a randomised, double-blind, phase 2 trial. The Lancet Oncology. 2012; 13:897-905.

52. Locati LD, Licitra L, Agate L, Ou SH, Boucher A, Jarzab B, Qin S, Kane MA, Wirth LJ, Chen C, Kim S, Ingrosso A, Pithavala YK, Bycott P, Cohen EE. Treatment of advanced thyroid cancer with axitinib: Phase 2 study with pharmacokinetic/pharmacodynamic and quality-of-life assessments. Cancer. 2014; 120:2694-2703.

53. Schlumberger MJ, Elisei R, Bastholt L, Wirth LJ, Martins RG, Locati LD, Jarzab B, Pacini F, Daumerie C, Droz JP, Eschenberg MJ, Sun YN, Juan T, Stepan DE, Sherman SI. Phase II study of safety and efficacy of motesanib in patients with progressive or symptomatic, advanced or metastatic medullary thyroid cancer. Journal of clinical oncology. 2009; 27:3794-3801.

54. Sherman SI, Wirth LJ, Droz JP, Hofmann M, Bastholt L, Martins RG, Licitra L, Eschenberg MJ, Sun YN, Juan T, Stepan DE, Schlumberger MJ. Motesanib diphosphate in progressive differentiated thyroid cancer. The New England journal of medicine. 2008; 359:31-42.

55. Hartwick EW, Curthoys NP. BPTES inhibition of hGA(124551), a truncated form of human kidney-type glutaminase. Journal of enzyme inhibition and medicinal chemistry. 2012; 27:861-867.

56. Xiang Y, Stine ZE, Xia J, Lu Y, O'Connor RS, Altman BJ, Hsieh AL, Gouw AM, Thomas AG, Gao P, Sun L, Song L, Yan B, Slusher BS, Zhuo J, Ooi LL, et al. Targeted inhibition of tumor-specific glutaminase diminishes cell-autonomous tumorigenesis. The Journal of clinical investigation. 2015; 125:2293-2306.

57. Emadi A, Jun SA, Tsukamoto T, Fathi AT, Minden MD, Dang CV. Inhibition of glutaminase selectively suppresses the growth of primary acute myeloid leukemia cells with IDH mutations. Experimental hematology. 2014; 42:247-251.
58. Erickson JW, Cerione RA. Glutaminase: a hot spot for regulation of cancer cell metabolism? Oncotarget. 2010; 1:734-740. doi: 10.18632/oncotarget.208.

59. Katt WP, Antonyak MA, Cerione RA. Simultaneously targeting tissue transglutaminase and kidney type glutaminase sensitizes cancer cells to acid toxicity and offers new opportunities for therapeutic intervention. Molecular pharmaceutics. 2015; 12:46-55.

60. Simpson NE, Tryndyak VP, Pogribna M, Beland FA, Pogribny IP. Modifying metabolically sensitive histone marks by inhibiting glutamine metabolism affects gene expression and alters cancer cell phenotype. Epigenetics. 2012; 7:1413-1420.

61. Gross MI, Demo SD, Dennison JB, Chen L, ChernovRogan T, Goyal B, Janes JR, Laidig GJ, Lewis ER, Li J, Mackinnon AL, Parlati F, Rodriguez ML, Shwonek PJ, Sjogren EB, Stanton TF, et al. Antitumor activity of the glutaminase inhibitor CB-839 in triple-negative breast cancer. Molecular cancer therapeutics. 2014; 13:890-901.

62. Jacque N, Ronchetti AM, Larrue C, Meunier G, Birsen R, Willems L, Saland E, Decroocq J, Thiago TT, Lambert M, Poulain L, Hospital MA, Sujobert P, Joseph L, Chapuis N, Lacombe $\mathrm{C}$, et al. Targeting glutaminolysis has antileukemic activity in acute myeloid leukemia and synergizes with BCL-2 inhibition. Blood. 2015; 126:1346-1356.

63. Wang Q, Beaumont KA, Otte NJ, Font J, Bailey CG, van Geldermalsen M, Sharp DM, Tiffen JC, Ryan RM, Jormakka M, Haass NK, Rasko JE, Holst J. Targeting glutamine transport to suppress melanoma cell growth. International journal of cancer. 2014; 135:1060-1071.

64. Robbins RJ, Wan Q, Grewal RK, Reibke R, Gonen M, Strauss HW, Tuttle RM, Drucker W, Larson SM. Realtime prognosis for metastatic thyroid carcinoma based on 2-[18F]fluoro-2-deoxy-D-glucose-positron emission tomography scanning. The Journal of clinical endocrinology and metabolism. 2006; 91:498-505.

65. Henry LR, Lee HO, Lee JS, Klein-Szanto A, Watts P, Ross EA, Chen WT, Cheng JD. Clinical implications of fibroblast activation protein in patients with colon cancer. Clinical cancer research. 2007; 13:1736-1741.

66. Bullock M, O'Neill C, Chou A, Clarkson A, Dodds T, Toon C, Sywak M, Sidhu SB, Delbridge LW, Robinson BG, Learoyd DL, Capper D, von Deimling A, Clifton-Bligh RJ, Gill AJ. Utilization of a MAB for BRAF(V600E) detection in papillary thyroid carcinoma. Endocrine-related cancer. 2012; 19:779-784. 